\title{
SMALL AND MEDIUM ENTERPRISES: DISCOVERING THE COMMUNITY RESOURCES IN KAMPONG PARIT SERONG SUB-DISTRICT OF KUALA SELANGOR
}

\author{
Munira Saaidin and Rohaizah abd. Latif \\ Faculty of Business \& Technology, UNITAR International University, Malaysia
}

\begin{abstract}
The purpose of this study is to discover the potential product to be developed for rural tourism through small and medium enterprises (SMEs) in Kampung Parit Serong, Hujong Permatang Sub-District, Kuala Selangor. The data for this research was collected via observation, unstructured interview, and collection of secondary data. The findings for this research are divided into two (2) parts which are analysis checklist on community resources and site analysis. The study indicates that Kampung Parit Serong has grown many potential village entrepreneurs that have came up with various products and services through small and medium enterprises that can be further commercialized as a unique tourism product development for rural areas. The findings are small and medium enterprises in Kampung Parit Serong were found to have most potential in accommodation, traditional food like snacks, biscuits, and cakes, as well as health and medical supplies. The results have implications for the role of tourism in small and medium business growth and improving rural livelihoods and poverty reduction through business and employment opportunity, income generation and self-reliance.
\end{abstract}

Key words: Small and medium enterprises (SME), rural tourism, tourism product development, Kampung Parit Serong

Cite this Article: Munira Saaidin and Rohaizah Abd. Latif, Small and Medium Enterprises: Discovering the Community Resources in Kampong Parit Serong SubDistrict of Kuala Selangor, International Journal of Management, 11(12), 2020, pp 1742-1751.

http://iaeme.com/Home/issue/IJM?Volume=11\&Issue=12

\section{INTRODUCTION}

As the most developed and industrialized state of the country, Selangor may not be a major tourist destination in Malaysia, yet it is centrally located on the west coast of Peninsular Malaysia and surrounds the Federal Territory of Kula Lumpur and Putrajaya, which may help to draw the attention of potential number of tourists in the future. According to Department of 
Statistics Malaysia, Selangor received the highest domestic visitor arrivals in 2018 with a total of 30.2 million visitors. Being the highest number of domestic tourisms receipt with a total of RM13.2 billion. Despite, Selangor is highly developed in the infrastructure, the state is still preserving some of the finest nature reserves, lifestyles, and cultures. Selangor which covers the area about 7, 931 km ${ }^{2}$ and consists of nine (9) districts namely, Gombak, Klang, Kuala Langat, Kuala Selangor, Petaling, Sabak Bernam, Sepang, Ulu Langat, (Hulu Langat) and Ulu Selangor (Hulu Selangor).

Named after the river confluent, Kuala Selangor is the second largest district and old royal capital of Selangor. Located on the west coast of Selangor, Kuala Selangor is an interesting historical district that has been developed since the 16th century. With the area $1,178 \mathrm{~km}^{2}$, Kuala Selangor consists of nine (9) sub-districts namely, Api-Api, Bestari Jaya, Ijok, Jeram, Kuala Selangor, Pasangan, Tanjong Karang, Ujong Permatang and Ulu Tinggi.

Situated on the north-west coast of Kuala Selangor, bordering with Tanjong Karang on the north, the settlement of the sub-district of Hujong Permatang began with the Bugis Empire which first landed in Kampung Permatang in Kuala Selangor in the 16th century. By 1700, they dominated the Selangor both politically and economically and had established the present Sultanate of Selangor. There are six (6) areas under the sub-district of Ujong Permatang namely, Kampung Sungai Yu, Kampung Sungai Terap, Kampung Permatang, Kampung Ujong Permatang, Kampung Parit Serong and Kampung Sungai Gulang-Gulang. This research focuses on the village area of Ujong Permatang which is Kampung Parit Serong.

This village was opened by immigrants from the Java island since the end of $18^{\text {th }}$ century and the name of Kampung Parit Serong started with a village that was split by a 'Parit' or ditch for drainage which was askew, looking different from its usual long and narrow rectangular shape. Unfortunately, this 'Parit' is not existed anymore today in the village due to the environmental changes and natural factors. Kampung Parit Serong is a small traditional Malay village located at the remote area that is neighbored by other villages such as Kampung Sungai Gulang-Gulang and Kampung Seri Tiram Jaya of Tanjong Karang sub-district.

The research issues addressed whether small and medium enterprises able to be a core element to promote Kampung Parit Serong as a new-found tourism destination. This is because, tourism has not been the main priority to Kampung Parit Serong. There have been no specific activities, programs or projects aimed at tourism development. This study addressed to discover and promote small and medium enterprises of Kampung Parit Serong in contributing to a new rural tourism destination. The findings from this study could contribute to the community to reduce poverty by generating income-earning opportunities for the local community, increasing employment opportunities from tourism activities and encouraging the self-reliance of the community through small and medium enterprises in tourism product development (University of Hawai, 2005).

Thus, the purpose of the research was to:

- Discover the potential product to be developed for rural tourism through small and medium enterprises in Kampung Parit Serong.

- Assess the availability and conditions of the existing resources.

- Determining the potential tourism products as tool for economic growth. 


\section{IMPLEMENTED CONCEPTUAL FRAMEWORK}

The following implemented conceptual framework depicted the variables examines in this study.

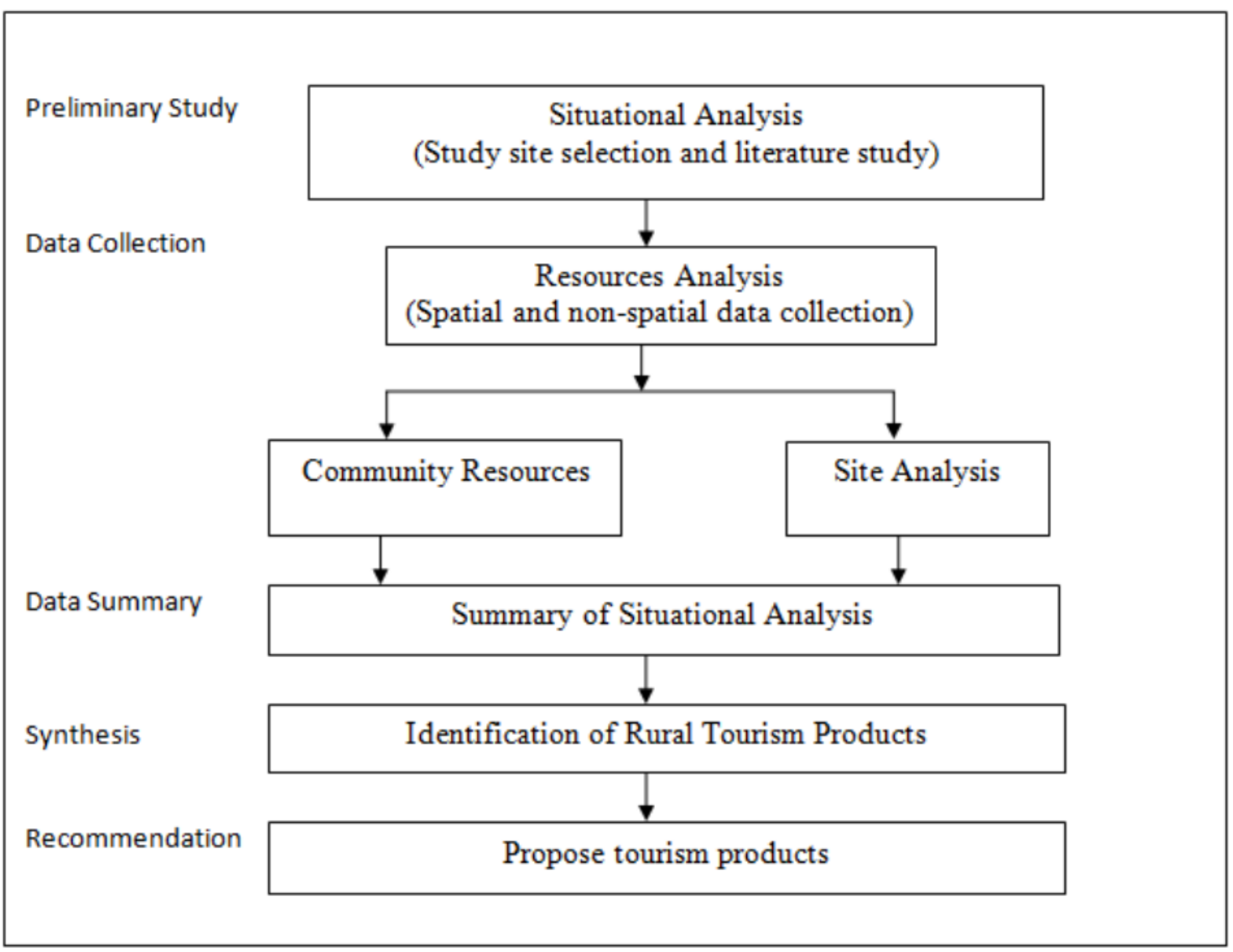

Figure 1 Implemented Conceptual Framework

\section{LITERATURE REVIEW}

World Tourism Organization (WTO) used rural tourism concept for defining tourism product that gives to visitors a personalized contact, a taste of physical and human environment of countryside and as far as possible, allow them to participate in the activities, traditions and lifestyles of local people (Negrusa, Cosma, \& Bota, 2007). Tourism has become increasingly important in rural communities in Malaysia during the past ten years. It was a component of planned growth identified in the Seventh Malaysia Plan (1996-2000) as a means to offer another possible income stream in communities and to boost international tourism as a generator of employment and as a source of foreign exchange. Ngah (2009) examined the various rural development strategies undertaken by the Malaysia government since independence and make a broad assessment of its impact. Tourism product development in rural area appears to be able to improve living conditions of its people, through improvement of rural economic activities, poverty eradication, provision of infrastructure and amenities.

Small and medium enterprises are found in a wide array of business activities, ranging from the single artisan producing agricultural implements for the village market, the coffee shop at the corner, the internet café in a small town to a small sophisticated engineering or software firm selling in overseas markets and a medium-sized automotive parts manufacturer 
selling to multinational automakers in the domestic and foreign markets. The owners may or may not be poor; the firms operate in very different markets (urban, rural, local, national, regional and international); embody different levels of skills, capital, sophistication and growth orientation, and may be in the formal or the informal economy (OECD, 2004).

Emdad Hossain (2011) studied that the contribution of small and medium enterprises to the Malaysian economy is relatively low when compared with the industrial countries and other developing countries, which range between $40 \%$ and $60 \%$ of GDP. The quote shows Malaysian SME has around 30\% contribution to their economy. Most obstacles due to: the lack of relevant institutions and infrastructure, the experience and the expertise necessary to successfully operate in a competitive market economy, low income suppresses demand for SMEs and prevents the formation of investment capital and results in policy mistakes, including the inconsistency and instability of policies. As a result, some of them cutting down or shutting down the business. Unfortunately, it will effect on national economy at sharp point.

On the other hand, small and medium enterprises are key factors for developing economies since it is best practice for economic growth which supports the transformation of the economy by creating jobs and helping the innovation and adaptation of the economic system (Hossain, 2011). Gunu (2004) and Aremu (2010) supported this view that small and medium enterprises from tourism provide income, savings, and employment generation. They are seen as veritable engines for the development of entrepreneurial capabilities and indigenous technology which will generate employment in the country. The relationship between tourism and small and medium businesses was also examined by Page, Forer, and Lawton (1999). They looked at the role of tourism and business development in relation to finance, marketing, human resource issues and the importance of tourism in the annual turnover of these businesses.

\section{RESEARCH METHODOLOGY}

The research design used for this study was qualitative research with combinations of exploratory study and descriptive design. It was deemed as the most appropriate method that could provide feedback in a concise manner and also and an economical way of collecting a large amount of data (Krathwohl, 1998). Descriptive design was used to provide the outcome of the study which represented a description of the various resources examined. With the help of secondary data, an analysis was carried out combining all the information collected from the various sources.

Primary Data was collected via Face-to-face discussions and with the with the local community, community leaders, and local authorities. The discussions and interviews were conducted with the guide of a set of semi-structured, open-ended questions that were developed to derive significant information on the identified traditional foods.

\section{STUDY FINDINGS}

There are two (2) findings being observed in this study: (1) community resources, and (2)site analysis.

Finding 1: Community Resources - study on population, community background, source of income and economic activities of small and medium enterprises and local people perception on tourism development

Finding 2: Site Analysis - encompasses the economic area, facilities and services, availability of transportation, utilities, and accessibility. 


\subsection{Community Resources}

The total number of houses in Kampung Parit Serong are about 120-130 houses with the population is approximately 1000 people which the majority of 99 percent of them are Malay while one percent is Chinese and Indian. Most of the Malay community is Javanese and still retain the Malay customs. The main activities of the locals are recreational activities like futsal, kick volleyball or 'sepak takraw' and fishing, community activities like volunteerism activities or 'gotong-royong' and socializing as well as religious activities to tighten their bonds. The major household transportation modes of the residence are motorbike, bicycle, and car. The major sources of household income are farming, oil palm planting, paddy planting at the neighbored village, self-employed and small and medium enterprises. There are a few small and medium enterprises that can be identified in the study area such as accommodation, traditional food like snacks, biscuits and cakes and health and medical supplies.

\subsubsection{Accommodation}

There is a homestay identified in Kampung Parit Serong, namely Amin Homestay Ada Kolam Renang or Amin Homestay with Swimming Pool owned by Encik Amin. Born into a large family, with many of his siblings have already moved outside the village, Encik Amin, decided to refurbish his extra-large character home to provide homestay facilities suitable for big groups comprising a large number of guests. This is because, finding suitable and affordable accommodation for a large group is not always easy, especially under one roof. Thus, helping the community by offering homestay service is the right decision. This homestay offers an affordable accommodation service under one roof suitable for groups comprising a large number of guests as it can accommodate an estimated of fifty (50) to sixty (60) people at one time. This homestay offers ten (10) rooms equipped with single size beds and queen size beds ( 3 rooms with air conditioner, 7 other rooms with ceiling fans including one (1) room for senior citizen or disabled people), eight (8) bathrooms, a mini hall, a dining area, a kitchen and a swimming pool (60 ft long x $30 \mathrm{ft}$ wide). The idea of this swimming pool is to provide opportunity for homestay guests and not to forget, the village community especially to the children and Muslim women to learn to swim besides recreational activity with an affordable price of RM3 for children and RM6 for adults. Other services offered such as meals, wi-fi, swimming, futsal, fishing, nature walk, sightseeing and agro visits.

\subsubsection{Traditional Snacks}

JAR'S Industri Makanan Istimewa or JAR's Special Food Industry was established since 1991 before officially registered in 2001. This business is owned by a single mother named Puan Siti Jaroha Binti Amri. With no high education and no background in business, she was just an ordinary housewife and a single mother who used to be self-employed by using sewing and baking skills to earn funds. She had long been active in joining the woman society at the village and from that, she built interest towards entrepreneurship and development of the village community especially employment opportunity for women. She had actively taking part in lots of training, seminar and programmes like entrepreneurship, food packaging, management and finance organized mostly by The Community Development Department (KEMAS) and other organizations.

Puan Siti Jaroha then decided to start for her own SME independently by attending many food carnivals, exhibitions, expos and showcases like the International Halal Products Expo 2007 to market her product besides selling her products to the middlemen. Through this business, she has helped ten (10) female from the village by hiring them to help with in her small snack processing centre. The responsibility of training for her workers was undertaken 
by KEMAS. Additionally, this business constantly receives many visitations from the local ministers and the international delegations. The specialty of JAR'S is that the snacks or kerepek are made from traditional recipes and ingredients with the addition of prawns, vegetables and other selected ingredients to maintain the quality of the aroma, beauty, durability and taste. Among the products produced are Mekar Kacang, Keropok Bawang, Siput Jalur, Makmur, Mini Popia, Popia Kuntum and Bahulu Gulung.

\subsubsection{Traditional Biscuits}

Kak Ton's Enterprises is specialized in traditional biscuits and cookies making which is owned by a retired KEMAS teacher and a single mother, Puan Sarina Binti Sarman, 63. By attending programmes and training from the Federal Agriculture Marketing Authority (FAMA), she builds her own home-based business which started since three (3) years ago with the help of two (2) female workers and her family as the middlemen. According to Puan Sarina, to start for the small business, she spent her Employees Provident Fund (EPF) money as capital to purchase the oven, processing machine and other bakery equipments due to not getting any capital support from the local authority. The startup capital for this business was made up almost RM1000 and the result was a profit of almost RM3000. Among the products produced are Makmur, Dahlia, Tart, Jejari, Apam Gula Hangus, Kerepek Ubi Kayu and also Frozen Karipap. Most of the customers are the villagers and there are also outsiders from Kuala Lumpur. The busiest time would be during the festive season especially Hari Raya Aidilfitri as many customers make their orders and reservations here. The spirit of Puan Sarina self-reliance effort benefits her in terms of income earning by engaging in the small and medium enterprise.

\subsubsection{Traditional Cake}

Specialized in making traditional cake of Bahulu for gifts and events, this small and medium enterprise has no brand name yet. This business has been in the family since 2008 established by Puan Salimah Bt Yon, but now this business was transferred to her daughter, Puan Salina Binti Puji, and her husband. From just a part time business, this family decided to go further, and they got assistance in the form of capital, training, skills, and baking machinery from the Agriculture Department of District Office.

The types of Bahulu that they produce are Bahulu Cermai, Bahulu Lapis, Bahulu Gulung and Bahulu Pecah Lapan. Most of the raw materials are from Selayang Wholesale Market. The specialty of their Bahulu and the filling which is pineapple jam are all self-made and their freshly baked Bahulu can be kept for two (2) weeks long. According to Puan Salina, the quality and durability of Bahulu depends on the baking processes and techniques. Besides Bahulu, Puan Salina also has other business such as selling Sambal Tempe and day-to-day business Nasi Lemak and Kuih-Muih in the morning and opening burgers stall in the evening. The spirit of this family self-reliance effort benefits them in terms of income earning by engaging in the small and medium enterprise. It is obviously indicated in the SME annual report 2015-2016, it has been defined entrepreneurship as one of the key elements particularly in a small and medium enterprise (SME) as it gives 'life' to the business.

\subsubsection{Health and Medical Supplies}

Dr. (Hom) Hj Rahmattullah Bin Hj Mohamad Sidek is the founder of Pusat Rawatan Homeopati dan Akupuntur or Homeopathy and Acupuncture Treatment Centre and the only one that exists in Kampung Parit Serong. He is over 60s and is a retired teacher getting inspired to start for his own traditional treatment centre at home for the benefit of community. Most of his patients are the local villagers and also the outsiders such as from Kuala Selangor and Sabak Bernam. According to him, modern medication is drug-based, causing any number 
of side-effects which are treated with more drugs. Traditional medication is another alternative treatment which has been quite popular in recent days. Side effects are less likely to occur because it contains natural ingredients. Among the products produced are Minyak Sawit Dara or Virgin Palm Oil and Minyak Kelapa Dara or Virgin Coconut Oil. Virgin Palm Oil is high in vitamin $\mathrm{E}$ is good for the eyes, curing Alzheimer, heart disease and diabetes. It can be eaten together with rice, traditional cakes and bread. Virgin Coconut Oil is rich in lauric acid which can cure any kinds of skin problems, improve our body immune and metabolism system, and protect from ultraviolet rays.

The majority of the village community of Kampung Parit Serong were satisfied with their way of life, yet when questioning about tourism development at the site of their villages, most of them were uncertain and hesitant about the potential in bringing their village to be developed as a new tourism destination despite of having variety of small and medium enterprises operated in the village. This is because, according to the village community, they have lack of special attraction or criteria to be developed as a successful tourism destination. Generally promoting tourism through small and medium enterprises is an opportunity for additional income and employment and providing a better quality of life.

\subsection{Site Analysis}

With $60 \%$ of its land usage for agriculture plantation and residential areas for $40 \%$, the local village activities in Kampung Parit Serong comprises of agriculture and small and medium enterprises. Most of the village community has the opportunity to manage their own lands, orchards and gardens and utilizing the existing resources to meet their needs and source of living such as for the use of their small and medium enterprises activities.

Community hall, recreational area, playground, food stalls and schools are important facilities existed for the purpose of serving the community. Another important facility that can be found in Kampung Parit Serong is the mosque as majority of the residents are Malay Muslims.

There is no public transport within the study area. Residents have to go to Bandar Malawati Bus Terminal (about $10 \mathrm{~km}$ from Hujong Permatang) to take buses provided that link Kuala Selangor to Kuala Lumpur and Sabak Bernam. The bus is numbered 141 (colored white and red with 'Selangor' written on the side). There are also Cityliner buses from Klang. To go further into chosen destination, taxis are available to facilitate the residents and visitors to their destinations.

In terms of availability of utilities, the areas are providing electricity, water and telecommunication to the community. Besides, the residential roads in the research area were tarred but in average condition. Uneven narrow road surface may cause problem especially to the heavy vehicle like trucks that frequently passing on the residential roads. There is also no proper road sign available for Kampung Parit Serong at the main road. This may cause confusion and difficulty to the visitors as this village is situated somewhat at the remote area. Visitors have to pass Kampung Sungai Gulang-Gulang first and turn left from the main road before entering the village.

\section{SUMMARY AND CONCLUSIONS}

Kampung Parit Serong have the potential to develop as a new rural tourism destination but there is still a need for some improvement in the aspects of accessibility, road signs, drainage system, facilities and services and involvement of communities. In this globalization era, is also recommended for Kampung Parit Serong to have own blogs or website as this can be a really useful tool to promote their village and small and medium enterprises products to the potential market and also to the eye of the world. Furthermore, the study would also 
recommend for creating a need for space to sell those products together. This can be seen as a one stop shopping center for small and medium enterprises entrepreneurs to display and promote their products as well as to attract visitors.

Last but not least, the involvement of local communities plays a vital role for the development of Kampung Parit Serong as a new rural tourism destination. The ideas to promote the sites are a good proposal as this activity may add to the income of the local population. The sale of goods and services related to tourism activity as the multiplier effects which are able to increase the income of a community which has a dependency on a limited number of activities and sources (Saaidin, M. 2012). Besides providing support in quality control of local products in terms of packaging, marketing, partnerships with tourism-related agencies, government and local authorities should raise awareness among the local community concerning the importance of their participation in the tourism activities. This is because, majority of them were uncertain and unsure about the potential in bringing their village to be developed as a new tourism destination. Excuses like no special attractions should not be raised, as they should have been proud of the existing variety small and medium enterprises in their village and what they could produce to grab the numerous tourist attentions.

The aim of this research paper is to discuss about the potential of Kampung Parit Serong to be developed as a new rural tourism destination through promotion of small and medium enterprises. This village has positive elements which are just in need for some enhancement and improvement for the sustainability of the area. In addition, education and awareness programs from the government and local authorities are the answers in order to promote awareness concerning the importance of their participation in the tourism activities. Any small and medium enterprises or tourism activities, implementation and development will ensure benefits to the local community of Kampung Parit Serong which is contribution to the local economy, improving rural livelihoods, poverty reduction, business and employment opportunity, income generation and self-reliance.

\section{RECOMMENDATIONS}

The study also suggests of proposing two (2) new package tours for rural tourism at Kampung Parit Serong. The packages are dedicated for local and international tourists especially to the student, special interest and business groups who wish to experience the different village environment without failed in bringing new informative knowledge home.

\section{Package A: Health Tour}

Table 1 Proposed Itinerary for Health Tour at Kampung Parit Serong

\begin{tabular}{|l|l|}
\hline \multicolumn{1}{|c|}{ Location } & \multicolumn{1}{c|}{ Activities } \\
\hline Amin Homestay Ada Kolam Renang & Refreshment provided upon arrive \\
& Learn-to-swim program by professionals \\
& Swimming activities and competition \\
& Lunch provided \\
\hline Pusat Rawatan Homeopati dan Akupuntur & Consultation \\
& Experience the traditional treatment \\
& Rest and Relaxation \\
& Refreshment provided upon departure \\
\hline
\end{tabular}




\section{Package B: Educational Tour (Choose ONE area of interest)}

Table 2 Proposed Itinerary for Educational Tour at Kampung Parit Serong

\begin{tabular}{|l|l|}
\hline \multicolumn{1}{|c|}{ Location } & \multicolumn{1}{|c|}{ Activities } \\
\hline JAR'S Industri Makanan Istimewa & Visit to traditional snacks processing centre \\
& Demonstration of snacks making \\
& Food testing \\
& Learn the simplest recipe \\
& Make your own snacks and bring home \\
\hline Kak Ton's Enterprise & Visit to traditional biscuits processing centre \\
& Demonstration of biscuits making \\
& Food testing \\
& Learn the simplest recipe \\
& Make your own biscuits and bring home \\
\hline Bahulu Enterprise & Visit to Bahulu processing centre \\
& Demonstration of Bahulu making \\
& Food testing \\
& Learn the simplest recipe \\
& Make your own Bahulu and bring home \\
\hline
\end{tabular}

\section{REFERENCES}

[1] Aremu, M. A. (2010). Small and Medium Scale Enterprises As A Means of Employment Generation and Capacity Building In Nigeria. Paper Presented at the International Conference on Management and Enterprise Development on "Intellectuals and New Strategies for Sustainability Development of the Third World" in Conference Center, University of Ibadan, Ibadan, Nigeria.

[2] Emdad Hossain, S. M. (2011). Small and Medium Enterprise: Clear Pathway to Bright Future By Using Fundamental Visionary Life Cycle and Difficulties Overcome Diagram. International Journal of Trade, Economics and Finance, 2 (5), October 2011, 402-406.

[3] Gunu, U. (2004). Small Scale Enterprises in Nigeria: Their Start Up, Characteristics, Sources of Finance, and Importance. Ilorin Journal of Business and Social Sciences, 9 (1 \& 2), 36 43.

[4] Krathwohl, D. R. (1998). Methods of educational and social science research: An integrated approach (2nd. ed.). New York: Longman.

[5] Negrusa, A. L., Cosma, S. A., \& Bota, M. (2007). Romanian rural tourism development a case study: rural tourism in Maramures. International Journal of Business Research, 7 (4), July 2007.

[6] Ngah, I. (2009). Rural Development in Malaysia. Malaysia's Economy, Past, Present and Future, Chapter 2, ed. Ishak Yussof. Kuala Lumpur: Malaysian Strategic Research Centre. 2009.

[7] Organisation For Economic Co-Operation And Development. (2004, June). Promoting Entrepreneurship And Innovative SMEs In a Global Economy: Towards a More Responsible And Inclusive Globalisation. Paper presented at the $2^{\text {nd }}$ OECD Conference of Ministers Responsible for Small and Medium-Sized Enterprises (SMEs). Retrieved April 13, 2012 from http://www.oecd.org/dataoecd/6/7/31919278.pdf

[8] Page, S. J., Forer, P., Lawton, G. R. (1999). Small Business Development and Tourism: Terra Incognita?. Tourism Management, 20, 435-459. 
Small and Medium Enterprises: Discovering the Community Resources in Kampong Parit Serong Sub-District of Kuala Selangor

[9] Saaidin, M. (2012). Discovering Ecotourism Products in the Community of Kampung Kempadang and Kampung Deraka. International Journal of Contemporary Research in Business. Vol 3, page $83-91$.

[10] University of Hawaii. (2005). Assessment of the Potential Tourism of Kampuan, Ranong Province. The Southeast Asia Office of the School of Travel Industry Management, University of Hawaii at Mano. Retrieved April 13, 2012 from

http://www.crc.uri.edu/download/Khampuan_Tourism_Assessment.pdf 